\title{
The association between ABO, RH blood types and eating behaviour
}

\section{$A B O$ ve $R H$ kan tipleri ile yeme davranışı arasındaki ilişki}

\author{
Serpil ÇEÇEN ${ }^{1} \oplus$, Canan EREN ${ }^{2} \odot$
}

\begin{abstract}
Aim: The aim of the present study is to reveal controlled eating, uncontrolled eating and emotional eating behaviours in women referred to the outpatient clinic of Sports Physiology with complaints of obesity, and to search whether an association exists between $A B O$ blood types as well as Rh factor and these behaviours using Three-Factor eating Questionnaire (TFEQ).
\end{abstract}

\begin{abstract}
Method: The women between 18 and 65 years of age who referred because of obesity consisted the obesity group $(n=197)$ whereas a control group ( $n=95)$ was created from non-obese women who referred to the blood bank as blood donors. Body heights of the women were measured at standing position without shoes. A complete blood analysis was performed including body weight, body mass index, fat percentage, fat weight and lean body weight through bio-impedance (Tanita-BC-418 MA III). The participants were asked to reply the three-factor Eating Questionnaire (TFEQ)-18) which is an international questionnaire evaluating controlled eating, uncontrolled eating and emotional eating behaviour. Blood type and Rh factor analyses were performed in the blood bank. The patient data collected within the scope of the study were analysed through IBM Statistical Package for the Social Sciences (SPSS) for Windows 20.0 package program.
\end{abstract}

Results: Cognitive restraint was detected to be higher in the blood type $A$ when compared with blood type $O$ whereas uncontrolled eating and emotional eating behaviour were not affected by $A B O$ blood types and $R h$ factor.

Conclusion: A significant result for controlled restriction only in blood type A may guide new studies that will investigate the effect of $A B O$ blood group antigens and $R h$ factors on eating behaviour.

Keywords: Obesity, blood groups, eating behaviour öz

\begin{abstract}
Amaç: Çalışmamızın amacı, Spor Fizyolojisi Polikliniğine obezite nedeniyle başvuran kadınlarda Three-Factor Eating Questionnaire (TFEQ) kullanarak kontrollü yeme, kontrolsüz yeme ve emosyonel yeme davranışını ortaya koymak ve bu davranışların $A B O$ kan grupları ve Rh faktörü ile ilişkisininin olup olmadığını araştırmaktır.
\end{abstract}

Yöntem: On sekiz-altmış beş yaş arası obezite nedeniyle başvuran kadınlardan obezite grubu ( $n=197)$, kan bankasına kan dönorü olarak başvuran obez olmayan kadınlardan kontrol grubu oluşturuldu (n=95). Düz zeminde, çıplak ayakla boy uzunlukları ölçüldü. Daha sonra bioimpedans (Tanita-BC-418 MA III) cihazında kilo, beden kitle indeksi, yağ yüzdesi, yağ ağırlığı ve yağsız ağırlığı gösteren tüm vücut analizi yapıldı. Kontrollü yeme, kontrolsüz yeme ve emosyonel yeme davranışını ölçen uluslararası düzeyde kullanılan, ülkemizde uygunluğu gösterilmiş çalışmaları olan üç faktörlü beslenme anketini (Three-Factor Eating Questionnaire (TFEQ)-18) doldurmaları istendi. Kan grupları ve Rh faktörünün tayini kan bankasında gerçekleştirildi. Çalışma kapsamında toplanan hasta verileri IBM Statistical Package for the Social Sciences (SPSS) for Windows 20.0 paket programı ile analiz edildi.

Bulgular: Cognitive restraint (Bilişsel kısıtlama) A kan grubunda O grubuna gore daha yüksek oranda belirlenirken, kontrolsüz yeme ve emosyonel yeme davranışının $A B O$ kan gruplarından ve Rh faktöründen etkilenmediği belirlendi.

Sonuç: Bu çalışmada yalnızca A kan grubunda kontrollü kısıtlama açısından anlamlı sonuç belirlenmesi $A B O$ kan grubu antijenlerinin ve Rh faktörünün yeme davranışı üzerine etkisini araştırmak açısından daha yeni çalışmalara yol gösterici olabilir.

Anahtar kelimeler: Obesite, kan grupları, yeme davranışı

Received: 17.08 .2018

Accepted: 11.10 .2018

${ }^{1}$ Marmara University Pendik Training and Research Hospital, Department of Sports Physiology, İstanbul, Turkey

${ }^{2}$ Marmara University Pendik Training and Research Hospital, Department of Blood Bank, İstanbul, Turkey

Corresponding author: Serpil Çeçen, Marmara University Pendik Training and Research Hospital, Department of Sports Physiology, İstanbul, Turkey e-mail: tahirer34@gmail.com

ORCID ID's:

S.Ç. 0000-0002-7908-5208, C.E. 0000-0003-4726-8840 


\section{INTRODUCTION}

Since obesity is a significant health problem whose incidence increases rapidly all over the world; number of investigations on obesity also increase. Obesity is defined as a supraphysiological increase of adipose tissue in the body ${ }^{1}$. Increase in adipose tissue leads to an increase in the risk of development of some diseases including Type 2 diabetes mellitus, coronary heart disease and cancer ${ }^{2}$. Obesity has been known to have multifactorial etiology and also associated with the eating behaviour of the individual. Food type choice, food intake and meal time are determined by eating behaviour ${ }^{3}$. Eating behaviour may vary in certain cases such as different mood, environmental and social factors ${ }^{4}$. Therefore, it is important to understand why we eat.

Three-Factor Eating Questionnaire (TFEQV) is a method used for such objective which was firstly published by Stunkard and Messick in 1985. The questionnaire includes 51 items and evaluates the desire to eat in three categories as as restraint, disinhibition and hunger ${ }^{5}$. Later, Karlsson et al. ${ }^{6}$ revised the aforesaid questionnaire and limited with 18 questions which assess cognitive restraint, uncontrolled eating and emotional eating. The three eating behaviours assessed by TFEQ-18 include cognitive restraint (questions $2,11,12,15,16$, and 18), uncontrolled eating (questions 1, 4, 5, 7, 8, 9, 13, 14 and 17) and emotional eating (questions 3,6 , and 10 ). Cognitive restraint is defined as being consciously careful in food selection not to gain weight ${ }^{7}$. Uncontrolled eating is defined as a strong desire for food consumption without thinking its consequences, emotional eating is also defined as increased food consumption in response to negative emotional stimuli such as anxiety, depression and anger ${ }^{6,8}$.

$A B O$ blood groups were first identified by Karl Landsteiner in 1901 according to presence of $A$ and $B$ antigens on membrane of red blood cells. Landsteiner and Alexander Wiener identified the Rh factor together in 1940-19419,10. The antigens of the ABO blood group system are complex carbohydrate molecules on the extracellular surface of red blood cell membranes $^{11}$. ABO antigens are also highly expressed on the surface of a variety of human cells and tissues including the epithelium, sensory neurons, platelets, and the vascular endothelium ${ }^{12}$. Although existence of the association between blood types and the mood is limited with previous studies, it was shown that groups $O$ and $B$ are active, aggressive, progressive, and positive; and groups $A$ and $A B$ are conservative, passive, defensive, negative personalities ${ }^{13}$. Since the association between the mood and eating behaviour is known, the aim of the present study is to show if any association exists between the blood types and eating behaviour ${ }^{14}$.

\section{MATERIAL and METHODS}

This study was conducted in the Sports Physiology Clinic of the Marmara University Pendik Training and Research Hospital, Istanbul, Turkey. The subjects in the obese group were the female outpatients of the clinic aged between 18 and 65 years old. A control group was created from non-obese individuals who referred to donate blood to the hospital's blood bank. Body height was measured on a flat surface without shoes; weight, BMI, fat percentage, fat mass and fat free mass of the patients were determined using a bio-impedance device (Tanita-BC-418 MA III). After collection of $2 \mathrm{ml}$ of blood from each patient into EDTA containing tubes, $\mathrm{ABO}$ and $\mathrm{Rh}$ blood groups were determined via Forward Reverse Microplack method.

Statistical methods: The patient data collected within the scope of the study were analysed using IBM Statistical Package for the Social Sciences (SPSS) for Windows 20.0 package program. Frequency and percentage were used for discrete data whereas mean \pm standard deviation, median, minimum and maximum values were used for continuous data. The independent sample's T-test was used to compare averages of two groups whereas ANOVA test was utilized to compare averages of three groups. Chi-Square Test was used to compare two discrete groups. The change in questionnaire scores according to the study gro- 
ups was examined; ANCOVA Test was used to analyse the effect of blood type. The $p$ value below 0.05 was accepted as statistically significant.

Approval of the Ethics Committee: The present study was approved by the Research Ethics Committee. Participants were informed that their participation is completely voluntary; and written consent was obtained from each participant.

\section{RESULTS}

Table 1 shows average values for age, weight, body mass index, fat percentage, fat weight and fat -free weight of obese and control individuals who took part in our study. The average body weights for the obese, and the control groups were 90 , and $55.8 \mathrm{~kg}$, respectively.

Table 2 shows the distribution of blood groups. While obese group had a higher percentage of $A$ blood type, O blood type percentage was higher in the control group.

Table 3 illustrates the Rh factor distribution. Both obese and control groups had higher percentage of Rh positive values.
Table 2. Distribution of Blood groups.

\begin{tabular}{llll}
\hline Blood Group & & $\mathbf{n}$ & $\%$ \\
\hline Obesity $(\mathrm{n}=197)$ & 0 & 57 & 28.9 \\
& A & 84 & 42.6 \\
& B & 29 & 14.7 \\
& AB & 27 & 13.7 \\
Control $(n=95)$ & 0 & & \\
& A & 40 & 42.1 \\
& B & 33 & 34.7 \\
& AB & 15 & 15.8 \\
Overall $(n=292)$ & 0 & 7 & 7.4 \\
& A & & \\
& B & 97 & 33.2 \\
& AB & 117 & 40.1 \\
& & 44 & 15.1 \\
& & 34 & 11.6 \\
\hline
\end{tabular}

Table 3. Distribution of Rh factor.

\begin{tabular}{llll}
\hline Rh Factor & & $\mathbf{n}$ & $\mathbf{\%}$ \\
\hline Obesity ( $\mathrm{n}=197)$ Positive & 177 & 89.8 \\
& Negative & 20 & 10.2 \\
Control $(\mathrm{n}=95)$ & Positive & 78 & 82.1 \\
& Negative & 17 & 17.9 \\
Overall $(\mathrm{n}=292)$ & Positive & 255 & 87.3 \\
& Negative & 37 & 12.7 \\
\hline
\end{tabular}

The cognitive restraint was detected to be higher in blood group A than blood group 0 ; and uncontrolled, and emotional eating behaviours were not affected by $A B O$ blood groups and Rh factor (Tables 4, 5, 6).

Table 1. Distribution of demographic characteristics of the Participants.

\begin{tabular}{|c|c|c|c|c|c|c|c|c|}
\hline & & $\begin{array}{l}\text { Age } \\
\text { (year) }\end{array}$ & $\begin{array}{l}\text { Height } \\
(\mathrm{cm})\end{array}$ & $\begin{array}{l}\text { Weight } \\
\text { (kg) }\end{array}$ & $\begin{array}{l}\text { Body Mass Index } \\
\text { (BMI) }\end{array}$ & $\begin{array}{l}\text { Body Fat } \\
\text { Percentage }\end{array}$ & $\begin{array}{l}\text { Body Fat } \\
\text { Mass }\end{array}$ & $\begin{array}{l}\text { Body Muscle } \\
\text { Mass }\end{array}$ \\
\hline \multirow{5}{*}{ Obesity (n=197) } & Mean & 33.7 & 159.9 & 90.1 & 35.2 & 40.8 & 37.9 & 52.2 \\
\hline & Median & 34.0 & 159.0 & 84.4 & 33.4 & 40.0 & 33. & 50.8 \\
\hline & Std. Deviation & 7.6 & 6.2 & 22.6 & 7.8 & 6.8 & 15.7 & 7.6 \\
\hline & Minimum & 17.0 & 143.0 & 55.8 & 24.3 & 25.6 & 15.6 & 38.4 \\
\hline & Maximum & 54.0 & 180.0 & 167.6 & 65.5 & 63.1 & 99.0 & 77.6 \\
\hline \multirow[t]{5}{*}{ Control (n=95) } & Mean & 30.7 & 161.0 & 55.8 & 21.4 & 24.0 & 14.0 & 41.6 \\
\hline & Median & 30.0 & 161.0 & 55.0 & 21.1 & 24.0 & 13.5 & 41.6 \\
\hline & Std. Deviation & 7.6 & 6.2 & 8.9 & 2.7 & 6.6 & 6.1 & 3.6 \\
\hline & Minimum & 17.0 & 137.0 & 35.1 & 16.6 & 7.8 & 3.7 & 31.4 \\
\hline & Maximum & 49.0 & 179.0 & 99.3 & 39.8 & 46.9 & 46.6 & 52.8 \\
\hline \multirow[t]{5}{*}{ Overall (N=292) } & Mean & 32.7 & 160.3 & 78.9 & 30.7 & 35.3 & 30.2 & 48.8 \\
\hline & Median & 33.0 & 160.0 & 74.9 & 29.7 & 36.3 & 27.1 & 47.8 \\
\hline & Std. Deviation & 7.7 & 6.2 & 25.0 & 9.2 & 10.3 & 17.4 & 8.2 \\
\hline & Minimum & 17.0 & 137.0 & 35.1 & 16.6 & 7.8 & 3.7 & 31.4 \\
\hline & Maximum & 54.0 & 180.0 & 167.6 & 65.5 & 63.1 & 99.0 & 77.6 \\
\hline
\end{tabular}


Table 4. Comparison results of subgroups of eating questionnaire according to blood groups.

\begin{tabular}{llllll}
\hline Blood Group (Obesity) & $\mathbf{n}$ & Mean & Std. Deviation & $\mathbf{p}$ \\
\hline Cognitive restraint & 0 & 57 & 2.42 & 0.614 & $\mathrm{p}<0.05$ \\
& $\mathrm{~A}$ & 84 & 2.73 & 0.588 & \\
& $\mathrm{~B}$ & 29 & 2.70 & 0.623 & \\
Uncontrolled Eating & $\mathrm{AB}$ & 26 & 2.57 & 0.658 & \\
& 0 & 57 & 2.31 & 0.663 & 0.954 \\
& $\mathrm{~A}$ & 84 & 2.24 & 0.669 & \\
Emotional Hunger & $\mathrm{B}$ & 29 & 2.29 & 0.716 & \\
& $\mathrm{AB}$ & 26 & 2.26 & 0.715 & \\
& 0 & 57 & 2.68 & 1.006 & 0.579 \\
& $\mathrm{~A}$ & 84 & 2.45 & 0.985 & \\
& $\mathrm{~B}$ & 29 & 2.51 & 0.932 & \\
& $\mathrm{AB}$ & 27 & 2.58 & 0.927 & \\
\hline
\end{tabular}

Table 5. Results of subgroups of eating questionnaire according to $\mathrm{Rh}$ factor.

\begin{tabular}{|c|c|c|c|c|c|}
\hline \multicolumn{2}{|l|}{ Rh Factor (Obesity) } & \multirow{2}{*}{$\begin{array}{l}\mathbf{n} \\
176 \\
20\end{array}$} & \multicolumn{3}{|c|}{ Mean Std. Deviation $p$} \\
\hline Cognitive restraint & $\begin{array}{l}\text { Positive } \\
\text { Negative }\end{array}$ & & $\begin{array}{l}2.59 \\
2.78\end{array}$ & $\begin{array}{l}0.617 \\
0.642\end{array}$ & 0.208 \\
\hline Uncontrolled Eating & $\begin{array}{l}\text { Positive } \\
\text { Negative }\end{array}$ & $\begin{array}{l}176 \\
20\end{array}$ & $\begin{array}{l}2.29 \\
2.14\end{array}$ & $\begin{array}{l}0.661 \\
0.801\end{array}$ & 0.360 \\
\hline Emotional Hunger & $\begin{array}{l}\text { Positive } \\
\text { Negative }\end{array}$ & $\begin{array}{l}177 \\
20\end{array}$ & $\begin{array}{l}2.54 \\
2.55\end{array}$ & $\begin{array}{l}0.963 \\
1.088\end{array}$ & 0.987 \\
\hline Rh Factor (Control) & & $\mathbf{n}$ & Mear & Std. D & $P$ \\
\hline Cognitive restraint & $\begin{array}{l}\text { Positive } \\
\text { Negative }\end{array}$ & $\begin{array}{l}78 \\
17\end{array}$ & $\begin{array}{l}2.31 \\
2.28\end{array}$ & $\begin{array}{l}0.651 \\
0.606\end{array}$ & 0.873 \\
\hline Uncontrolled Eating & $\begin{array}{l}\text { Positive } \\
\text { Negative }\end{array}$ & $\begin{array}{l}78 \\
17\end{array}$ & $\begin{array}{l}1.99 \\
1.96\end{array}$ & $\begin{array}{l}0.624 \\
0.620\end{array}$ & 0.852 \\
\hline Emotional Hunger & $\begin{array}{l}\text { Positive } \\
\text { Negative }\end{array}$ & $\begin{array}{l}78 \\
17\end{array}$ & $\begin{array}{l}1.93 \\
1.86\end{array}$ & $\begin{array}{l}0.787 \\
0.825\end{array}$ & 0.732 \\
\hline
\end{tabular}

Table 6. Results of subgroups of eating questionnaire according to blood groups.

\begin{tabular}{llllll}
\hline Blood Group (Control) & $\mathbf{n}$ & Mean & Std. Deviation & $\mathbf{p}$ \\
\hline Cognitive restraint & 0 & 40 & 2.31 & 0.639 & 0.740 \\
& A & 33 & 2.32 & 0.655 & \\
& B & 15 & 2.35 & 0.666 & \\
& AB & 7 & 2.04 & 0.598 & \\
Uncontrolled Eating & 0 & 40 & 2.00 & 0.584 & 0.476 \\
& A & 33 & 1.90 & 0.662 & \\
& B & 15 & 1.99 & 0.576 & \\
& AB & 7 & 2.31 & 0.735 & \\
Emotional Hunger & 0 & 40 & 1.99 & 0.821 & 0.763 \\
& A & 33 & 1.82 & 0.791 & \\
& B & 15 & 1.86 & 0.814 & \\
& AB & 7 & 2.09 & 0.629 & \\
\hline
\end{tabular}

Table 7. Evaluation of eating behaviours according to groups.

\begin{tabular}{llllll}
\hline & Group & $\mathbf{n}$ & Mean & Std. Deviation & $\mathbf{p}$ \\
\hline Cognitive Restraint & Obesity & 196 & 2.61 & 0.620 & $\mathrm{p}<00.1$ \\
& Control & 95 & 2.30 & 0.640 & \\
Uncontrolled Eating & Obesity & 196 & 2.27 & 0.676 & $\mathrm{p}<00.5$ \\
& Control & 95 & 1.99 & 0.620 & \\
Emotional Hunger & Obesity & 197 & 2.54 & 0.973 & $\mathrm{p}<00.1$ \\
& Control & 95 & 1.92 & 0.790 &
\end{tabular}

\section{DISCUSSION}

The frequency of cognitive restraint was detected to be higher in obese people with blood type A when compared to those with blood type $\mathrm{O}$; it was also detected that uncontrolled eating and emotional behaviours are not affected by $A B O$ blood groups and Rh factor.

\section{The association between eating behaviours and obesity:}

There are studies suggesting that eating behaviour is an important factor for obesity and depends on BMI and gender. It was shown that uncontrolled eating, cognitive restraint and emotional eating behaviour increase with increasing $\mathrm{BMI}^{15}$. Restraint and Disinhibition scores were shown to be higher in females when compared with males ${ }^{16}$. In a study where TFEQ was used, it was noted that women who had higher levels of worry and anxiety more frequently displayed much higher level of emotional eating behavior ${ }^{17}$. In a study carried out with two groups including nonobese adults and teenagers, cognitive restraint (CR) and emotional eating (EE) were detected more frequently in females of both groups according to TFEQR18 scores ${ }^{18}$. The cognitive restraint scale scores were found to be significantly lower whereas uncontrolled eating and emotional eating scale scores were detected to be lower in the individuals with lower BMI when compared to overweighed individuals in a study conducted on adolescents between 17 and 19 years of age in Kırklareli University; however, the results were not statistically significant ${ }^{19}$. In the present study, uncontrolled eating, cognitive restraint and emotional eating behaviour appears to be more frequent in the obesity group when compared with the control 
groups (Table 7). Although there is not any significant difference between groups $A$ and $O$ in terms of body weight and $\mathrm{BMI}$, while restriction behaviour was less frequently detected in patients with blood group A when compared with those with group $\mathrm{O}$.

The association between the blood groups and obesity:

There are studies suggesting the possible association between obesity and blood groups. In a study conducted on Turkish seafarers, groups AB Rh (+) and AB $\mathrm{Rh}(-)$ were associated with the highest $(13.7 \%$ and $13.6 \%$, respectively) and $\mathrm{B} \mathrm{Rh}(+)$ and $\mathrm{B} \mathrm{Rh}(-)$ with the lowest percentages $(11.6 \%$ and $11.3 \%$, respectively) of obese subjects ${ }^{20}$. The individuals with $B \mathrm{Rh}$ (+) blood type were found to be more susceptible for obesity. This case was explained by the assertion that patients with blood group B may be more inclined to obesity ${ }^{21,22}$. However, there was not any association detected between obesity and blood groups in a study conducted in Saudi Arabia ${ }^{23}$.

\section{The association between blood groups and diseases:}

It was considered in 1953 that the individuals with A blood group had more risk for gastric cancer ${ }^{24}$, in another study, the non-O blood groups were found to be associated with renal cell cancer, coronary artery disease, myocardial infarction, venous thrombosis ${ }^{25-}$ ${ }^{27}$ which was suggested as dependent to the antigens and $A B O$ locus. The significance in controlled restriction behaviours in the blood group $A$ in the present study supports the aforesaid studies suggesting the possible effect of antigen and gene locus.

The association between the blood groups and mood:

Despite conflicting outcomes, there are studies suggesting the association between blood groups and psychiatric diseases. The studies have detected that psychiatric diseases are three-fold more common in individuals with $A B$ blood groups when compared with other groups ${ }^{28}$. Groups $A$ and $O$ were found to be genetically associated with schizophrenia and depression, respectively ${ }^{29}$.

In previous studies, dopamine-3-hydroxylase enzyme activity which induces transformation of dopamine to norepinephrine was found to be lower in blood group $\mathrm{O}$; therefore the individuals with blood group $\mathrm{O}$ were considered as more susceptible for psychiatric diseases. Dopamine-3-hydroxylase enzyme activity was shown to be controlled by a locus dependent on ABO blood group locus ${ }^{30-32}$.

Despite different incidence rates and conflicting studies, the association shown between depression and blood groups is considered to affect eating behaviour. The association between emotional eating behaviour and depression is well known ${ }^{33}$. It is also known that such eating behaviour uses the dependence mechanism ${ }^{34}$. Existence of an association between $A B$, Rh negative blood group and opioid addiction was considered to be related to locus of a gene on chromosome $6^{35}$. However, any association between $\mathrm{Rh}$ factor and emotional eating behaviour could not be detected in the present study.

\section{CONCLUSIONS}

Since the association between obesity and diseases is known, we wanted to show the effects of blood groups on eating behaviours due to the blood group antigens. However, we believe that the significant result obtained in blood group A only would guide the further studies that will search the effect of blood group antigens and $\mathrm{ABO}$ gene locus on eating behaviour.

\section{REFERENCES}

1. Ng M, Fleming T, Robinson M, Thomson B, Graetz N, Margono $C$, et al. Global, regional, and national prevalence of overweight and obesity in children and adults during 1980-2013: a systematic analysis for the Global Burden of Disease Study 2013. Lancet. 2014;30;384:766-81. https://doi.org/10.1016/S0140-6736(14)60460-8

2. Peter G. Kopelman. Obesity as a medical problem. Nature. 2000;404:635-643. https://doi.org/10.1038/35007508

3. Blundell JE, Stubbs RJ, Golding C, Croden F, Alam R, Whybrow 
S, et al. Resistance and susceptibility to weight gain: Individual variability in response to a high-fat diet. Physiology and Behavior. 2005;86:614-622. https://doi.org/10.1016/j.physbeh.2005.08.052

4. French SA, Epstein LH, Jeffery RW, Blundell JE, Wardle J. Eating behavior dimensions. Associations with energy intake and body weight. A review. 2012;59(2):541-549.

5. Stunkard AJ, Messick S. The three-factor eating questionnaire to measure dietary restraint, disinhibition and hunger. J Psychosom Res. 1985;29:71-83. https://doi.org/10.1016/0022-3999(85)90010-8

6. Karlsson J, Persson L-O, Sjöström L, Sullivan M. Psychometric properties and factor structure of the Three-Factor Eating Questionnaire (TFEQ) in obese men and women. Results from the Swedish Obese Subjects (SOS) study. Int J Obes. 2000;24:1715-25. https://doi.org/10.1038/sj.ijo.0801442

7. Hays NP, Bathalon GP, McCrory MA, Roubenoff R, Lipman R, Roberts SB. Eating behavior correlates of adult weight gain and obesity in healthy women aged 55-65 y. Am J Clin Nutr. 2002;75:476-83.

https://doi.org/10.1093/ajcn/75.3.476

8. Oliver G, Wardle J, Gibson EL. Stress and food choice: a laboratory study. Psychosom Med. 2000;62(6):853-65. https://doi.org/10.1097/00006842-200011000-00016

9. WM Watkins. The ABO blood group system: historical background. Transfusion Medicine. 2001;11:243-265. https://doi.org/10.1046/j.1365-3148.2001.00321.x

10. Hans Peter Schwarz. Historical Review. Karl landsteıner and his major contrıbutıons to haematology. British Journal of Haematology. 2003;121:556-565. https://doi.org/10.1046/j.1365-2141.2003.04295.x

11. Storry JR, Olsson ML. The ABO blood group system revisited: a review and update. Immunohematology. 2009;25:48-59.

12. Eastlund T. The histo-blood group $A B O$ system and tissue transplantation. Transfusion. 1998;38:975-88. https://doi.org/10.1046/j.1537-2995.1998.381098440863.x

13. Furukawa T. A study of temperament by means of human blood groups. Japanese Journal of Psychology. 1927;2:612-634. https://doi.org/10.4992/jjpsy.2.612

14. Christensen L. Effects of eating behavior on mood: a review of the literature. The International Journal of Eating Disorders. 1993;14:171-183. https://doi.org/10.1002/1098-108X(199309)14:2<171::AIDEAT2260140207>3.0.CO;2-U

15. Loffler A, Luck T, Then FS, Sikorski C, Kovacs P, Bottcher $Y$, et al. Eating Behaviour in the General Population: An Analysis of the Factor Structure of the German Version of the ThreeFactor-Eating-Questionnaire (TFEQ) and Its Association with the Body Mass Index. PloS one 2015;10:e0133977. https://doi.org/10.1371/journal.pone.0133977

16. Provencher V, Drapeau V, Tremblay A, Després J-P. Lemieux, S. Eating Behaviors and Indexes of Body Composition in Men andWomen from the Québec Family Study. Obes Res. 2003;11:783-792.

https://doi.org/10.1038/oby.2003.109

17. Mostafavi SA, Akhondzadeh S, Mohammadi MR, Eshraghian MR, Hosseini S, Chamari M, Keshavarz SA. The Reliability and Validity of the Persian Version of ThreeFactor Eating Questionnaire-R18 (TFEQ-R18) in Overweight and Obese Females. Iran J Psychiatry. 2017;12(2):100-108.

18. Lauzon B, Romon M, Deschamps V, Lafay L, Borys JM, Karlsson J, Ducimetie P, Charles MA, Fleurbaix Laventie Ville Sante (FLVS) Study Group. The Three-Factor Eating Questionnaire-
R18 Is Able to Distinguish among Different Eating Patterns in a General Population. J Nutr. 2004;134:2372-2380. https://doi.org/10.1093/jn/134.9.2372

19. Nogay NH. The role of psychological eating styles in obesity among Turkish adolescents: A cross-sectionalstudy The Journal of Pakistan Asociation. 2017;573-576.

20. Nas S, Fışkın R. A research on relationship between $A B O$ blood groups and body mass index among Turkish seafarers. International Maritime Health. 2017;68:140-146.

https://doi.org/10.5603/IMH.2017.0025

21. Sukalingam K, Ganesan K. Rhesus blood groups associated with risk to obesity and diabetes mellitus: A report on Punjabi population in Selangor, Malaysia. Int J Intg Med Sci. 2015;2(4):105-109.

22. Chandra T, Gupta A. Association and Distribution of Hypertension, Obesity and ABO Blood groups in Blood Donors. Iranian Journal of Pediatric Hematology Oncology. 2012;2:140-145.

23. Aboel-Fetoh NM, Alanazi AR, Alanazi AS, Alruwili AN. ABO blood groups and risk for obesity in Arar, Northern Saudi Arabia. Journal of the Egyptian Public Health Association. 2016;91:169-173.

24. Aird I, Bentall HH, Roberts JA. A relationship between cancer of stomach and the ABO blood groups. Br Med J. 1953;1:799-801. https://doi.org/10.1136/bmj.1.4814.799

25. Hee-Kyung Joha, Eunyoung Choa, and Toni K. Choueirie .ABO blood group and risk of renal cell cancer. Cancer Epidemiol. 2012;36:528-532.

https://doi.org/10.1016/j.canep.2012.07.001

26. Takagi $\mathrm{H}$, and Umemoto T. Meta-analysis of non-o blood group as an independent risk factor for coronary artery disease. American Journal of Cardiology. 2015;116;699-704. https://doi.org/10.1016/j.amjcard.2015.05.043

27. Dentali F, Sironi AP, Ageno W, Turato S, Bonfanti C, Frattini F, Crestani S, Franchini M. Non-O blood type is the commonest genetic risk factor for VTE: results from a meta-analysis of the literature. Semin Thromb Hemost. 2012;38:535-48. https://doi.org/10.1055/s-0032-1315758

28. Pisk SV, Tomislav Vuk T, Ivezić E, Jukić I, Bingulac-Popović J, Filipčić I. ABO blood groups and psychiatric disorders: a Croatian study Blood Transfus. 2018;15:1-6.

29. Irvine DG, Miyashita H. Blood types in relation to depressions and schizophrenia: a preliminary report. Can Med Assoc J. 1965;92:551-4.

30. Meijas-Aponte CA. Specificity and impact of adrenergic projections to the midbrain dopamine system. Brain Res. 2016;15:258-73. https://doi.org/10.1016/j.brainres.2016.01.036

31. Morison J. Exploring the link between ABO blood-group philosophy and stress-response. Eur J Clin Hynosis. 2004;5:16-30.

32. Wilson AF, Elston RC, Siervogel RM, et al. Linkage of gene regulating dopamine- $\beta$ hydroxylase activity and the $A B O$ blood group locus. Am J Hum Genet. 1988;42:160-6.

33. Van Strien $T$, Konttinen $H$, Homberg JR, Engels RC, Winkens LH. Emotional eating as a mediator between depression and weight gain. Appetite. 2016;100:216-24. https://doi.org/10.1016/j.appet.2016.02.034

34. Volkow ND, Wang GJ, Baler RD. Reward, dopamine and the control of food intake: implications for obesity. Trends Cogn Sci. 2011;15:37-46. https://doi.org/10.1016/j.tics.2010.11.001

35. Aflatoonian MR, Meymandi MS, Divsalar K, Mahmoudi M, Heravi G. Possible association between human blood types and opioid addiction. Am J Addict. 2011;20:581-4. https://doi.org/10.1111/j.1521-0391.2011.00170.x 